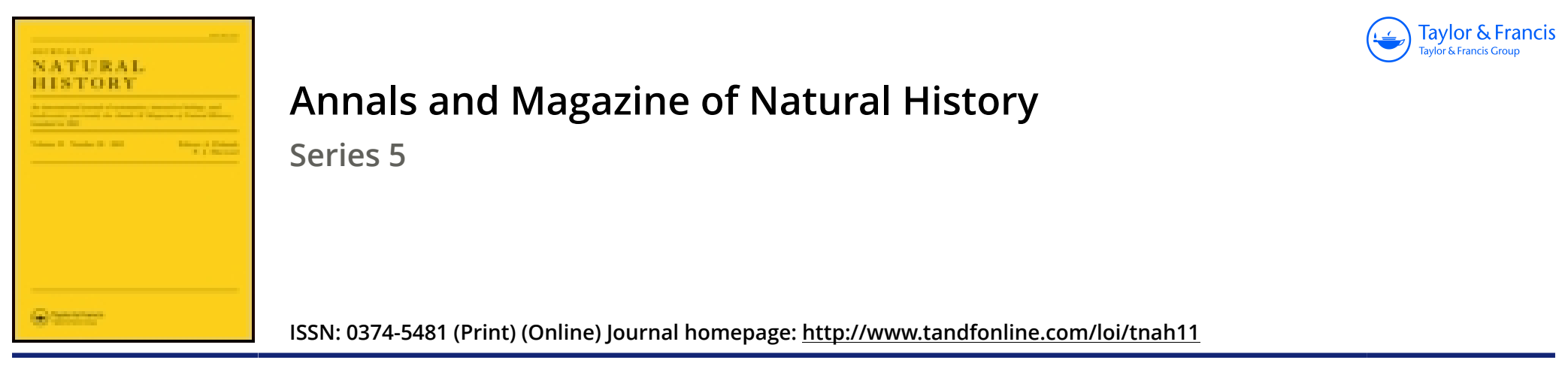

\title{
VIII.-Description of a new tailed Batrachian from Corea
}

\section{G.A. Boulenger}

To cite this article: G.A. Boulenger (1887) VIII._Description of a new tailed

Batrachian from Corea, Annals and Magazine of Natural History, 19:109, 67-67, DOI:

10.1080/00222938709460201

To link to this article: http://dx.doi.org/10.1080/00222938709460201

$$
\text { 盟 Published online: } 12 \text { Oct } 2009 .
$$

Submit your article to this journal $\sqsubset$

Џ Article views: 1

Q View related articles $\sqsubset$ 
VIII.-Description of a new Taited Batrachian from Corea. By G. A. Boulenger.

Hynobius Leechii, sp. n.

Palatine teeth forming a $\mathbb{V}$-shaped figure, which is broader than long; the length of one of the series, from anterior to posterior angle, equals one half of the width of the tongue. Head depressed, a little longer than broad; snout short, rounded. Body thrice and two thirds the length of the head; the distance from snout to gular fold contained nearly thrice in the distance from latter to cloaca. Limbs

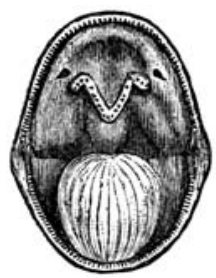
not meeting when adpressed; fifth toe well developed. Tail nearly as long as the distance between gular fold and vent, thick, compressed, not keeled, with vertical grooves, obtusely pointed posteriorly. Skin smooth; thirteen costal grooves; a vertebral groove. Blackish brown, above speckled with pale brownish; upper surface of tail pale brownish, with a few black dots.

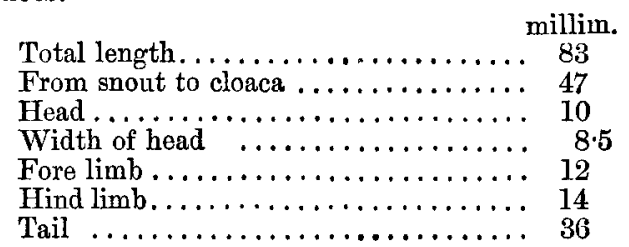

A single specimen formed part of a small collection of Batrachians made at Gensan, Corea, and presented to the Natural-History Museum by J. H. Leech, Esq. The other species are: Rana esculenta, var. japonica, Bufo vulgaris, and Hyla arborea, var. Savignyi.

Finding that the name Anaides, given by Baird in 1849 to a genus of Plethodontine newts ( $c f$. Cat. Batr. Caud. p. 52) is preoccupied (Westwood, 1841), I propose to change it to Autodax.

IX.-On the Genus Hindia, Duncan, and the Name of its Typical Species. By George Jennings Hinde, Ph.D., F.G.S.

DR. RAUFF's * able paper on this genus, a translation of which by Mr. W. S. Dallas appeared in the September number

* "Ueber die Gattung Hindia, Dunc.," Sitzungsb. der Niederrh. Gesell. zu Boun, Sitzung vom 10. Mar. 1886. 